\title{
Response of broccoli to foliar application of zinc and boron concentrations
}

\author{
Quratul Ain ${ }^{1}$, GoharAyub ${ }^{1}$, Mohammad Ilyas ${ }^{1}$, Manzoor Ahmad ${ }^{2}$, \\ Farzana Begum ${ }^{1}$, Luqman ${ }^{3}$, Ammara Saeed ${ }^{1}$, Mohammad Imtiaz Khan ${ }^{3}$ \\ and Kamran Shah ${ }^{1}$ \\ 1. Department of Horticulture,3Department of Weed Science, The University of Agriculture Peshawar-Pakistan \\ 2. Department of Agriculture, Bacha Khan University Charsadda-Pakistan \\ 3. Fodder Livestock Research and Development Department Peshawar-Pakistan \\ *Corresponding author's email: Ilyas_swati88@yahoo.com \\ Citation \\ QuratulAin, Gohar Ayub, Mohammad Ilyas, Manzoor Ahmad, Farzana Begum, Luqman, Ammara Saeed, \\ Mohammad Imtiaz Khan and Kamran Shah. Response of broccoli to foliar application of zinc and boron \\ concentrations. Pure and Applied Biology. Vol. 5, Issue 4, pp841-846. http://dx.doi.org/10.19045/bspab.2016.50105
}

Received: 22/06/2016

Revised: $27 / 07 / 2016$

Accepted: 04/08/2016

Online First: 13/08/2016

\section{Abstract}

An experiment to study the response of broccoli to foliar application of zinc and boron concentrations was carried out under field condition during 2013-14 at Horticulture Research Farm, The University of Agriculture Peshawar. Zinc at the rate of $(0,0.25,0.5$, and 1.0\%) and boron at the rate of $(0,0.25,0.5$, and $1.0 \%)$ were applied as a foliar spray using Randomized Complete Block Design with three replication. Maximum plant height $(40.49 \mathrm{~cm})$ and number of leaves plant ${ }^{-1}$ (13.08), were noted at $0.5 \% \mathrm{Zn}$, while $\mathrm{Zn} @ 1 \%$ resulted in maximum leaf weight $(9.66 \mathrm{~g})$ and maximum number of curd plant ${ }^{-1}$ (9.17. Regarding B maximum plant height $(39.31 \mathrm{~cm})$ was observed with $0.25 \%$ boron while minimum $(32.30 \mathrm{~cm})$ in plants sprayed with $1 \%$ boron. B @ 0.5\% resulted in maximum number of leaves plant ${ }^{-1}$ (12.83). Maximum leaf weight $(10.17 \mathrm{~g})$ and number of curds plant ${ }^{-1}(8.41)$ were noted at $1 \%$ boron. Among various treatments used zinc and boron levels at the rate of $0.5 \%$, showed better result in most of the growth and yield parameters.

Keywords: Broccoli; Zinc; Boron; Growth; Yield

\section{Introduction}

Broccoli (Brassica oleracae.Var. italica) belongs to family crucifereae. Crucifereae is also known as Cole crop which is considering a large group of plant i.e. Brussels sprouts, cabbage, cauliflower, Chinese cabbage, kale and kohlrabi. The word broccoli is derived from the Italian word broccoli which means "the flowering top of a cabbage [1]. All Cole crops grow best in hardy and cool weather [2]. Broccoli is shallow rooted crop, its root length is about $46-61 \mathrm{~cm}$. Broccoli is dicotyledonous biennial herbaceous for seed production and considered as annual when harvested for fresh consumption [3]. It is a cross pollinated crop and pollination occurs through insects. The seeds are produced inside the fruit, which is called silique [4]. Broccoli is green in color because of chlorophyll, which is present in the sepals of the floral buds, and that floral buds are grown as annual buds for its mature flower buds [1].Broccoli is mainly originated from 
Italy (2000 year ago). The species brassica oleraceae is classified from the cultivar of the Italic group. Broccoli can be grown best on alkaline soil. It can slightly tolerate $\mathrm{pH}$ $6.8-6.0$, broccoli can also grow best up to $\mathrm{pH}$ 7.6, if essential nutrients are not deficient. Generally broccoli requires fertilization in order to achieve responsible yields [5].

Zinc play very important role in growth and development of plants, for growth of plant it is very essential because it control the formation of indole tic acid. It also dramatically regulates the plant growth. For much enzymatic reaction zinc is very active, and also necessary for the synthesis of chlorophyll and carbohydrate formation, protein metabolism and sexual fertilization [6].Boron also play very important role in physiological and biochemical processes, because it is one of the most important plant micronutrient. Boron is essential for plant growth and development. Its application to the soil increased head yield of broccoli [7]. Hollow stem is an abiotic quality defect in broccoli, which shows this disorder in the stem extending from below the head or curd when the stem is normally cut. The disorder has been to be most severe when individual plants grow rapidly such as: wide spacing, high $\mathrm{N}$ fertilizer levels, warm weather, adequate moisture and, B deficiency [8]. There is potential for infection and spoilage after harvest in the walls of the cavities of hollow stem. This disorder is corrected by judicious application of $\mathrm{B}$ and nitrogenous fertilizer [9], [10]. The deficiency of boron mainly occurs in dry weather. However in mineral soil boron application has not been successful universally, while its foliar application generally gives more and faster affective result. Generally boron is applied when plants are young i.e about 3 inches $(8$ $\mathrm{cm})$ high. If the boron deficiency occur in soil second application may be required. Boron plays an important role in formation of protein, nucleic acid, cell division, cell membrane, integrity, cell wall formation and in ant oxidative system $[11,12]$.

\section{Materials and methods}

An experiment "Response of broccoli to foliar application of zinc and boron concentrations" was conducted at Horticulture Research Farm, The University of Agriculture Peshawar, Pakistan during the year 2013-14. The actual experimental plot was ploughed thoroughly before transplanting of the seedlings and well rotten farm yard manure was incorporated in the field. Forty eight sub plots were prepared for transplantation of seedlings row to row and plant to plant distance were kept $60 \mathrm{~cm}$ and $30 \mathrm{~cm}$ respectively. The experiment was laid out in randomized complete block design (RCBD) with two factors. The experiment contained 16 treatments which were repeated three times. Zinc sulphate was used as a source for zinc, while boric acid was used as source for boron. From $1 \mathrm{~kg}$ of zinc sulphate we were taking $0,0.25,0.5,1.0 \%$ concentration of zinc and also from $1 \mathrm{~kg}$ of boric acid we were take $0,0.25,0.5,1.0 \%$ concentration of boron and was applied as a foliar application after one month of transplantation. Plants were regularly observed and the data on growth parameters of broccoli was recorded on Plant height (cm), Number of leaves plant ${ }^{-1}$, Leaf weight (g) and Number of curds plant ${ }^{-1}$.

\section{Results and discussions}

\section{Plant height $(\mathbf{c m})$}

The maximum plant height $(40.49 \mathrm{~cm})$ was recorded in plants sprayed with zinc at 0.5 $\%$ closely followed by plant height (38.01 $\mathrm{cm}$ ), when Zinc was applied at $1 \%$, while minimum plant height $(29.81 \mathrm{~cm})$ was observed in control treatment. Regarding boron, maximum plant height $(39.31 \mathrm{~cm})$ was observed in plants sprayed with $0.25 \%$ boron, while the lowest plant height $(32.30$ $\mathrm{cm})$ was recorded in plants sprayed with 1 $\%$, boron.Plant height increased significantly 
with the increase concentration of zinc and boron [13].Plant height in broccoli was increased with foliar application of micronutrients [14]. Foliar application of zinc and boron significantly influenced the plant height in all stages of growth [15]. At final harvest, maximum plant height and number of branches plant ${ }^{-1}$ was recorded with zinc sulphate at $40 \mathrm{~kg} \mathrm{ha}^{-1}$ and borax $15 \mathrm{~kg}$ $\mathrm{ha}^{-1}$.Plantheight and number of branches increase due to synthesis of tryptophan in the presences of zinc, the growth of plant tissue is stimulated by tryptophan, the precursor of IAA [16]. Zinc has beneficial effect on plant height. Zinc is directly involving in photosynthesis and play vital role in shoot production. Boron plays a major role in synthesis of cell wall, occurrence of cell division, transportation of carbohydrates and hormones activation. Boron concentrations greatly improved plant height in broccoli [17]. Boron is associated with the cell wall development and with the process of cell differentiation, helping inthe root and shoots growth of the plant [18].

\section{Number of leaves plant ${ }^{-1}$}

The highest number of leaves plant ${ }^{-1}$ (13.08) was recorded in plants sprayed with zinc at $0.5 \%$, while minimum plant height (7.94 $\mathrm{cm})$ was observed in control plot. Maximum number of leaves plant ${ }^{-1}$ (12.83) was recorded in plants sprayed with $0.5 \%$ boron, while the lowest number of leaves (8.40) was recorded in control treatment. Zinc and boron concentrations significantly increased number of leaves in broccoli [13]. Number of leaves plant ${ }^{-1}$ was increased by increasing micronutrients concentration by foliar application [19]. The results also coincide with the results of [20], who reported that number of leaves in broccoli was increased by foliar application of zinc and boron. Zinc is essential for plant growth and play important role in physiological activities. Zinc help in transformation of carbohydrate and chlorophyll and also help in synthesis of protein. Zinc synthesized amino acid tryptophan, which in turn converts in to auxin (IAA) [21], reported that zinc have a major role in synthesis of amino acids and protein. Boron plays a great role in transport of carbohydrates and stimulates the activation of certain hormones. Deficiency of boron lead to leaves shrunken and become closed. The foliar application of boron can protect stomata from drying and help to remain opened. Same results were presented by [22], [23], [24] on broccoli growth as effected by zinc and boron concentrations.

\section{Leaf weight (g)}

The maximum leaf weight (9.66 g) was noted in plants sprayed with zinc at $1 \%$ closely followed by leaf weight $(8.93 \mathrm{~g})$ when Zinc was applied at $0.5 \%$, while minimum leaf weight (5.89 g) was recorded in control plot. In boron maximum leaf weight $(10.17 \mathrm{~g})$ was observed in plants sprayed with $1 \%$ boron, while the lowest leaf weight $(6.19 \mathrm{~g})$ was recorded in control plants [25].Increasing zinc and boron concentration significantly increased leaf weight in broccoli 9130. Same results were obtained by [22], [23], [24]. By increasing micronutrients concentration leaf weight in broccoli significantly increased, may be due to higher accumulation of the micronutrients in leaves, which can cause better photosynthesis, which ultimately results in better growth and bigger leaves.Zinc application significantly increased leaf weight in broccoli [26].Zinc is involved in respiration, photosynthetic carbon metabolism and indole acetic acid (IAA) metabolism [27]. Boron regulates stomata and guard cells in plants. The increasing levels of zinc and boron increased leaf weight, because of better photosynthesis and appropriate stomata opening.

\section{Number of curds plant ${ }^{-1}$}

The maximum number of curd plant ${ }^{-1}$ (9.17 $\mathrm{cm})$ was recorded in plants when sprayed 
with zinc at $1 \%$, while minimum number of curd $\operatorname{plant}^{-1}(5.50 \mathrm{~cm})$ was observed in control treatment.

The highest curdplant $^{-1}(8.41 \mathrm{~cm})$ was observed in plants sprayed with $1 \%$ boron, while the lowest number of curdplant $^{-1}(5.53 \mathrm{~cm})$ was observed in control treatment.Zinc play important role in synthesis of auxin and pollen formation [28]. Sufficient supply of boron improve the curd yield in crucifers, while boron deficiency occur browning and bitterness of curd. Boron also cause poor root growth and delayed crop maturity and quality deterioration of curd [13], reported that the highest curd was achieved by high level of zinc. Secondary curd yield and curd length was improved with high level of boron Application of boron increase curd yield significantly. The highest head yield was obtained with high dose of boron [29], reported that maximum head yield in cauliflower and broccoli significantly obtained when boron was applied at 1.5- 1.7 $\mathrm{kg} \mathrm{B} \mathrm{ha}{ }^{-1}$.

Table 1. Effect of different levels of foliar application of Zinc and boron on growth and yield of Broccoli

\begin{tabular}{|c|c|c|c|c|}
\hline Treatments & Plant height (cm) & $\begin{array}{c}\text { Number of leaves } \\
\text { plant }^{-1}\end{array}$ & Leaf weight (gm) & $\begin{array}{c}\text { Number of Curds } \\
\text { plant }^{-1}\end{array}$ \\
\hline \multicolumn{5}{|l|}{ Zinc levels } \\
\hline $\mathrm{Zn} 1$ & $29.81 \mathrm{c}$ & $7.94 \mathrm{c}$ & $5.89 \mathrm{c}$ & $5.50 \mathrm{c}$ \\
\hline $\mathrm{Zn} 2$ & $34.62 \mathrm{~b}$ & $9.81 \mathrm{~b}$ & $7.59 \mathrm{~b}$ & $6.97 \mathrm{~b}$ \\
\hline $\mathrm{Zn} 3$ & $40.49 \mathrm{a}$ & $13.08 \mathrm{a}$ & $8.93 \mathrm{a}$ & $7.50 \mathrm{~b}$ \\
\hline $\mathrm{Zn} 3$ & $38.01 \mathrm{a}$ & $10.20 \mathrm{~b}$ & $9.66 \mathrm{a}$ & $9.17 \mathrm{a}$ \\
\hline LSD $(\mathrm{P} \leq 0.05)$ & 2.32 & 1.53 & 1.07 & 2.04 \\
\hline \multicolumn{5}{|l|}{ Boron levels } \\
\hline $\mathrm{B} 1$ & $35.76 \mathrm{~b}$ & $8.40 \mathrm{c}$ & $6.19 \mathrm{c}$ & $5.53 \mathrm{c}$ \\
\hline $\mathrm{B} 2$ & $39.31 \mathrm{a}$ & $10.32 \mathrm{~b}$ & $7.20 \mathrm{c}$ & $7.63 \mathrm{ab}$ \\
\hline B3 & $35.53 \mathrm{~b}$ & $12.83 \mathrm{a}$ & $8.52 \mathrm{~b}$ & $7.57 \mathrm{~b}$ \\
\hline B4 & $32.30 \mathrm{c}$ & $10.20 \mathrm{bc}$ & $10.17 \mathrm{a}$ & $8.41 \mathrm{a}$ \\
\hline LSD $(\mathrm{P} \leq 0.05)$ & 2.32 & 1.53 & 1.07 & 2.04 \\
\hline \multicolumn{5}{|l|}{ Zinc $\times$ Boron } \\
\hline $\mathrm{Zn} 1 \times \mathrm{B} 1$ & 27.03 & 5.50 & 4.40 & 4.87 \\
\hline $\mathrm{Zn} 1 \times \mathrm{B} 2$ & 29.10 & 6.77 & 5.06 & 5.53 \\
\hline $\mathrm{Zn} 1 \times \mathrm{B} 3$ & 30.80 & 9.23 & 6.77 & 5.43 \\
\hline $\mathrm{Zn} 1 \times \mathrm{B} 4$ & 32.30 & 10.26 & 7.33 & 6.20 \\
\hline $\mathrm{Zn} 2 \times \mathrm{B} 1$ & 30.33 & 8.27 & 6.10 & 4.50 \\
\hline $\mathrm{Zn} 2 \times \mathrm{B} 2$ & 36.47 & 10.23 & 6.87 & 8.00 \\
\hline $\mathrm{Zn} 2 \times \mathrm{B} 3$ & 32.43 & 12.20 & 7.80 & 6.96 \\
\hline $\mathrm{Zn} 2 \times \mathrm{B} 4$ & 39.23 & 8.53 & 9.60 & 8.46 \\
\hline $\mathrm{Zn} 3 \times \mathrm{B} 1$ & 34.60 & 11.50 & 6.50 & 5.00 \\
\hline $\mathrm{Zn} 3 \times \mathrm{B} 2$ & 36.77 & 13.13 & 7.67 & 7.51 \\
\hline $\mathrm{Zn} 3 \times \mathrm{B} 3$ & 39.07 & 17.40 & 8.23 & 8.95 \\
\hline $\mathrm{Zn} 3 \times \mathrm{B} 4$ & 41.50 & 13.20 & 13.33 & 8.53 \\
\hline $\mathrm{Zn} 4 \times \mathrm{B} 1$ & 35.38 & 8.33 & 7.77 & 7.77 \\
\hline $\mathrm{Zn} 4 \times \mathrm{B} 2$ & 36.83 & 11.16 & 9.20 & 9.50 \\
\hline $\mathrm{Zn} 4 \times \mathrm{B} 3$ & 44.27 & 12.50 & 11.30 & 8.95 \\
\hline $\mathrm{Zn} 4 \times \mathrm{B} 4$ & 40.83 & 8.83 & 10.40 & 10.45 \\
\hline LSD $(\mathrm{P} \leq 0.05)$ & Ns & Ns & Ns & Ns \\
\hline
\end{tabular}




\section{Conclusion and recommendation}

On the basis of different results which were obtained it is concluded that Zinc and boron at the rate of $0.5 \%$ each resulted in better growth and yield of broccoli and hence recommended for optimum growth and yield of broccoli under the agroclimatic condition of Peshawar.

\section{Authors' contributions}

Conceived and designed the experiments: $G$ Ayub \& M Ilyas, Performed the experiments: Q Ain, Analyzed the data: $M$ Ahmad, Contributed reagents/ materials/ analysis tools: Department of Horticulture, Wrote the paper: M Ilyas.

\section{References}

1. Gray AR (1982) .Taxonomy and evolution of broccoli (Brassica oleraceavar Italica). Economic Botany 36: 397-410.

2. Baloch AF (1994). Vegetable crops. Horticulture National Book Foundation. Islamabad, pp 489-509.

3. Yamaguchi M (1983). World vegetables principles, production and nutritive values. AVI publishing company, INC Westport, connection, USA. Pp 405.

4. Brown HD \& Chester SH (1949). Vegetable science J.B Lippincott Company. New York pp.124-126.

5. Zeb A (1996). Effect of different levels of nitrogen, phosphorous and potash on the yield components of broccoli" Msc (hons) department of Hort. The Uni of Agri. Peshawar.

6. Tisdale SL, Nelson WL \& Beaton JD (1985). Soil and fertilization pp: 754

7. Yang Xian, Xiao Yan Chen, liu Z, Yang X, Chen XY \& Liu ZC (2000). Effects of boron and molybdenum nutrition on curd yield and and active oxygen metabolism in broccoli (Brassica oleracea var. italica) Acta Hort. Sinica 27(2): 112-116.

8. Vigier B \& Cutcliffe (1985). Influence of boron and nitrogen rate on incidence of hollow stem in broccoli. Canadian $J$ Plant Sci 65: 421-424.

9. Hipp BW (1974). Influence of nitrogen and maturity rate on hollow Stem in Broccoli. Hort Sci 9 (1): 68-69.

10. Trembalay N (1989). Effect of nitrogen sources and rates on yield and hollow stem development in broccoli. Canadian J. Plant Sci 69(3): 1049-1053.

11. Gupta U, Jame YW, Campbell CA, Leyshon AJ \& Nicholaichuk W (2002). Boron toxicity and deficiency: A review. Canadian Journal of Soil Science 65: 381-409.

12. Goldbach HE \& Wimmer M.A (2007). Boron in plants and animals. J plant Nutr Soil Sci 170(1): 39-48

13. Abd EL-ALL HM (2014). Improving growth, yield, quality and sulphoraphan content as anticancer of broccoli (Brassica oleraceaL. var. italica) plants by some fertilization treatments. Middle East Journal of Agriculture Research 3(1): 13-19.

14. Yildirim E, Guvenc I, Turan M \& Karatas A (2007). Effect of foliar urea application on quality, growth, mineral uptake and yield of broccoli (Brassica oleracea L., var. italica). Plant Soil Environment 53(3): 120-128.

15. Sanjay SK, Chankhar \& Rana MK (2009). Response of okra to zinc and boron micronutrients. Veg Sci 36(3 Suppl.) : 327-331.

16. Naruka IS, Gujar KD \& Lal G (2000). Effect of foliar application of zinc and molybedenum on growth and yield of okra . Haryana J Hort Sci 29(3-4): 266267.

17. Nadian H, Najarzadegan R, Saeid K, Gharineh MH \& Siadat A (2010). Effects of boron and sulfur application on yield and yield component of Bassica napusL. in a calcareous soil. World applied Sci J 11(1): 89-95. 
18. Kumar M \& Sen NL (2004). Effect of zinc, boron and gibberellic acid on growth and yield of cauliflower. Ann Agric Res New Series 25(4): 595-597.

19. Gad N \& Abd El-Moez MR (2011). Broccoli growth, yield quantity and quality as affected by cobalt nutrition. Plant Nutrition Dept., National Research Centre, Dokki, and Giza. Agric Bio l J N Am 2(2): 226-231.

20. Narayanamma $\mathrm{M}$, Chiranjeevi $\mathrm{CH} \&$ Riazuddin Ahmed S (2007). Effect of foliar application of micronutrients on the growth, yield and nutrient content of cabbage. In Andhra Pradesh.Vegetable Breeding Station, A.R. / ANG RangaAgri/. University Ra;endra Nagar Veg Sci 34(2): 213-214.

21. Zhi F, Ji-hua YU, Jian-ming XE \& Tirrong SV (2005). Effects of $\mathrm{Zn}$ on growth of broccoli seedling. J Gansu Agri Univ 73(1): 70-78.

22. Mahmud S, Haider J, Moniruzzaman M \& Islam MR (2007). Optimization of fertilizer requirement for broccoli under field condition. Bangladesh J Agri Res 32(3): 487-491.

23. Moniruzzaman M., Mozumder SN \& Islam (2008). Effects of Sulfur, Boron,
Zinc and Molybdenum on Yield and Profitability of Broccoli (Brassica oleracea L. Var. italic). J Agri and Rural Development 6(1): 55-61.

24. Islam $\mathrm{MH}$, Shaheb $\mathrm{MR}$, Rahman $\mathrm{S}$, Ahmed B, Islam AT \& Sarker PC (2010). Curd yield and profitability of broccoli as affected by phosphorus and potassium. Int J Sustain Crop ford 5(2): 1-7.

25. Asad A, Blamey FP \& Edwards DG (2003) Effect of boron foliar application on vegetative and production growth of Sunflower. Annals Botany 92: 565-570.

26. Lashkari CO, Makwana AN \& Meman MA (2007). Effect of zinc and iron on growth and yield of cauliflower (Brassica oleracea. var. Botrytis.) cv. Snowball.16. The Asia J Hort Ind 2(2): 277-279.

27. Marschner H (1995). Mineral Nutrition of Higher Plants. (2nd Ed). Academic press, London.

28. Hafeez B, Khanif $Y M$ \& Saleem M (2013). Role of zinc in plant nutrition. American Journal of Experiment.

29. Noor S, Rahman M, Shil NC, Nandy SK, Anwar MN (2000). Effects of boron and molybdenum on the yield and yield components of cauliflower. Bangladesh Hort 24(1 and 2): 123-127. 